\section{High Intensity Focused Ultrasound: Terapi Non-Invasif Efektif untuk Hipertensi Resisten}

\author{
Rizki Arisandi \\ Fakultas Kedokteran Universitas Lampung, Lampung, Indonesia. \\ Alamat Korespondensi: rizkiarisandi279@gmail.com
}

\begin{abstract}
Abstrak
Hipertensi resisten adalah tekanan darah yang tetap di atas target walaupun sudah menggunakan minimal tiga obat antihipertensi pada dosis maksimal yang dapat ditoleransi (salah satunya diuretik) atau tekanan darah yang membutuhkan minimal empat obat untuk mencapai target tekanan darah. Salah satu pendekatan tatalaksana hipertensi resisten adalah dengan menggunakan renal denervation. Berbagai metode renal denervation berkembang, mulai dari reseksi, kateter Radiofrequency Ablation (RFA), hingga High-Intensity Focused Ultrasound (HIFU). HIFU merupakan merupakan metode terbaru dan memiliki efektivitas yang cukup menjanjikan. Hasil uji pada hewan coba dan uji klinik pada manusia menunjukkan hasil yang baik. Selain itu, HIFU merupakan metode non-invasif sehingga dapat meminimalisir efek samping prosedur invasif atau bedah. Satu-satunya efek samping yang dilaporkan adalah nyeri punggung namun dapat diatasi menggunakan obat penghilang nyeri.
\end{abstract}

Kata Kunci: HIFU, Hipertensi resisten, Renal denervation

\section{High Intensity Focused Ultrasound: An Effective Non-Invasive Teraphy for Resistant Hypertension}

\begin{abstract}
Resistant hypertension is defined as blood pressure $(B P)$ remaining above therapy goal despite the use of three or more antihypertensive drugs at maximally tolerated doses (one ideally being a diuretic) or $B P$ that requires four or more agents to reach the blood pressure therapy goal. One approach used to treat resistant hypertension is renal denervation. Various methods have been developed, from the resection, Radiofrequency Ablation (RFA) catheter, to High-Intensity Focused Ultrasound (HIFU). HIFU is the newest method and has promising efficacy. The results of test in animal and clinical trial in humans are showing a good outcome. Moreover, HIFU is a non-invasive procedure so that able to minimize the undesirable effect of invasive or surgical procedure. The only reported side effect of this procedure is back pain which can be cured with painkiller medications.
\end{abstract}

Keywords: HIFU, Resistant Hypertension, Renal Denervation

\section{Pendahuluan}

Hipertensi telah menjadi masalah kesehatan di seluruh dunia, baik di negara maju maupun negara berkembang seperti Indonesia. ${ }^{1}$ Menurut WHO, diperkirakan sekitar 1,13 milyar orang di dunia menderita hipertensi, sekitar dua pertiga penderitanya tinggal di negara berpenghasilan rendah sampai sedang.
Pada tahun 2015, 1 dari 4 laki-laki dan 1 dari 5 perempuan mengalami hipertensi. ${ }^{2}$ Di Indonesia, prevalensi hipertensi yang terdiagnosis oleh tenaga kesehatan adalah sebesar $8,8 \% .^{1}$ Jika penduduk Indonesia berjumlah 237 juta jiwa, maka penderita hipertensi di Indonesia adalah 20,8 juta jiwa. ${ }^{3}$ Provinsi di Inonesia dengan prevalensi 
hipertensi tertinggi adalah Sulawesi Utara, yakni sebesar $13,2 \%{ }^{1}$

Menurut American Heart Association (AHA) 2017, hipertensi didefinisikan sebagai tekanan darah sistolik $>130 \mathrm{mmHg}$ dan tekanan diastolik $>80 \mathrm{mmHg} .{ }^{4}$ Hipertensi merupakan faktor risiko utama untuk penyakit kardiovaskular yang sering berakibat fatal. ${ }^{4}$ Setiap kenaikan tekanan sistolik sebesar 20 $\mathrm{mmHg}$ dan diastolik sebesar $10 \mathrm{mmHg}$, terjadi peningkatan risiko kematian dua kali lipat akibat stroke, penyakit jantung, dan penyakit yang berhubungan dengan pembuluh darah. ${ }^{5}$ Hipertensi dapat berakibat pada kerusakan organ, antara lain ginjal, jantung, otak, dan mata. $^{5}$

Hipertensi dapat dikendalikan menggunakan obat anti-hipertensi oral. Hingga saat ini telah tersedia 69 jenis obat yang terbagi dalam 15 golongan. ${ }^{6}$ Keberhasilan pengobatan farmakologi pada pasien hipertensi tergantung dari banyak faktor, antara lain kepatuhan pasien, dosis obat, kombinasi obat, kepatuhan terhadap pantangan memakan beberapa jenis makanan, efek samping pengobatan dan ketidakefektifan obat. ${ }^{7}$ Pasien yang mengalami kegagalan pengobatan dapat menderita hipertensi resisten atau hipertensi tak terkontrol. ${ }^{7}$ Hipertensi resisten adalah keadaan dimana tekanan darah tidak mencapai target walaupun sudah menggunakan paling sedikit tiga jenis kombinasi obat anti hipertensi dengan golongan berbeda, termasuk diuretik. ${ }^{8}$ Sekitar $10 \%$ pasien hipertensi di dunia menderita hipertensi resisten. ${ }^{8}$

Munculnya hipertensi resisten, dimana tekanan darah sudah tidak dapat dikontrol melalui terapi farmakologi menyebabkan perlunya metode lain yang efektif dalam penanganan hipertensi resisten. ${ }^{9}$ Metode baru dalam mengatasi hipertensi resisten menggunakan saraf simpatik ginjal (renal sympathetic nerve) sebagai target intervensi, yang disebut renal denervation (RDN). ${ }^{9}$ Persarafan simpatik ginjal memiliki peranan penting dalam patofisiologi hipertensi. ${ }^{10}$ Aktivasi serabut saraf efferen ginjal menyebabkan retensi garam, cairan dan aktivasi sistem renin-angiotensin-aldosteron, yang pada akhirnya meningkatkan tekanan darah. ${ }^{10}$

Beberapa teknik Renal Denervation (RDN) telah dikembangkan, seperti menggunakan operasi reseksi saraf splanknik ginjal yang diperkenalkan pada tahun $1934 .^{9,10,11}$ Sejak saat itu, Teknik lain yang menargetkan saraf ginjal dikembangkan, seperti kateter Radiofrequency Ablation (RFA) dan yang terakhir teknik HighIntensity Focused Ultrasound (HIFU) yang paling aman karena merupakan metode noninvasif, berbeda dengan kedua teknik yang berkembang sebelumnya. ${ }^{9,10,11}$

\section{Hipertensi Resisten}

Hipertensi atau tekanan darah tinggi adalah keadaan dimana tekanan sistolik $>130 \mathrm{mmHg}$ dan tekanan diastolik $>80 \mathrm{mmHg} .{ }^{4}$ Beberapa perhimpunan atau organisasi internasional juga mengeluarkan panduan mengenai definisi, pencegahan dan penatalaksanaan hipertensi yang menunjukkan adanya perbedaan nilai kategori tekanan darah dan target tekanan darah yang harus dicapai bagi penderita hipertensi pada keadaan tertentu. Berikut perbandingan kategori tekanan darah yang dikeluarkan oleh beberapa organisasi di dunia. ${ }^{5}$

Manajemen farmakologi dan perubahan gaya hidup masih menjadi rujukan utama terapi hipertensi. Beberapa faktor dapat mempengaruhi keberhasilan manajemen farmakologi, yang paling utama adalah kepatuhan pasien dalam meminum obat antihipertensi secara rutin. ${ }^{12}$ Ketidakpatuhan pasien menyebabkan kontrol tekanan darah semakin buruk dan berakibat terjadinya hipertensi resisten. ${ }^{13}$ Hipertensi resisten didefinisikan sebagai tekanan darah yang tetap diatas target walaupun sudah menggunakan minimal tiga obat antihipertensi pada dosis maksimal yang dapat ditoleransi (salah satunya diuretik) atau tekanan darah yang membutuhkan minimal empat obat untuk mencapai target tekanan darah. ${ }^{13}$

Belum ada data pasti mengenai prevalensi hipertensi resisten di dunia. Penelitian oleh Giannattasio di Italia menemukan prevalensi hipertensi resisten sebesar 17,4\%. ${ }^{14}$ Sedangkan menurut Freyhardt et al prevalensi hipertensi resisten sebesar $10 \% .^{8}$ Risiko penyakit kardiovaskular meningkat pada hipertensi resisten. ${ }^{15}$ Penelitian di Amerika Serikat menunjukkan bahwa penderita hipertensi resisten mengalami peningkatan risiko penyakit jantung iskemik sebesar 1,34 kali, peningkatan risiko gagal 
jantung kongestif sebesar 1,78 kali, dan penyakit ginjal kronik sebesar 1,84 kali dibanding penderita hipertensi non-resisten. ${ }^{15}$ Oleh karena itu sangat penting untuk menjaga tekanan darah pasien hipertensi resisten agar tidak terjadi kerusakan organ atau komplikasi lainnya. $^{21}$ Pendekatan tradisional berupa manajemen farmakologi seringkali gagal menjaga tekanan darah pasien hipertensi resisten sehingga diperlukan pendekatan terapi lain, salah satunya satunya menggunakan Renal Denervation $(\mathrm{RDN}){ }^{21}$

Tabel 1. Perbandingan Kategori Tekanan Darah dan Target Tekanan Darah ${ }^{5}$

\begin{tabular}{|c|c|c|c|c|}
\hline $\begin{array}{c}\text { Asosiasi / } \\
\text { Organisasi, Tahun } \\
\text { terbit }\end{array}$ & $\begin{array}{c}\text { Kategori Tekanan } \\
\text { Darah }\end{array}$ & $\begin{array}{l}\text { Tekanan } \\
\text { sistolik } \\
(\mathbf{m m H g})\end{array}$ & $\begin{array}{l}\text { Tekanan } \\
\text { diastolik } \\
\text { (mmHg) }\end{array}$ & Target tekanan darah \\
\hline JNC 7, 2003 & $\begin{array}{l}\text { Normal } \\
\text { Prehipertensi } \\
\text { Hipertensi derajat } 1 \\
\text { Hipertensi derajat } 2\end{array}$ & $\begin{array}{l}<120 \\
120-139 \\
140-159 \\
>160\end{array}$ & $\begin{array}{l}<80 \\
80-89 \\
90-99 \\
>100\end{array}$ & $\begin{array}{l}<140 / 90 \text { mmHg untuk semua } \\
\text { kategori tekanan darah } \\
<130 / 80 \mathrm{mmHg} \text { bagi penderita } \\
\text { diabetes dan penyakit ginjal } \\
\text { kronik }\end{array}$ \\
\hline JNC 8, 2014 & Tidak melampirkan $n$ & i kategori te & nan darah & $\begin{array}{l}150 / 90 \mathrm{mmHg} \text { bagi usia }>60 \text { tahun } \\
140 / 90 \mathrm{mmHg} \text { bagi penderita } \\
\text { diabetes }\end{array}$ \\
\hline ACP/AAFP, 2017 & \multicolumn{3}{|c|}{ Tidak melampirkan nilai kategori tekanan darah } & $\begin{array}{l}150 / 90 \mathrm{mmHg} \text { bagi usia }>60 \text { tahun } \\
140 / 90 \mathrm{mmHg} \text { bagi penderita } \\
\text { dengan risiko } \\
\text { kardiovaskular, atau riwayat } \\
\text { stroke atau TIA }\end{array}$ \\
\hline ACC/AHA, 2017 & $\begin{array}{l}\text { Normal } \\
\text { Meningkat } \\
\text { Hipertensi derajat } 1 \\
\text { Hipertensi derajat } 2\end{array}$ & $\begin{array}{l}<120 \\
120-129 \\
130-139 \\
>140\end{array}$ & $\begin{array}{l}<80 \\
<80 \\
80-89 \\
>90\end{array}$ & $\begin{array}{l}<130 / 80 \mathrm{mmHg} \text { untuk semua } \\
\text { kategori tekanan darah }\end{array}$ \\
\hline
\end{tabular}

\section{Renal Denervation (RDN)}

Persarafan simpatik ginjal memainkan peranan penting dalam patofisiologi hipertensi. ${ }^{16}$ Nervus renalis efferen berasal dari otak, melewati medulla spinalis, mencapai ginjal melalui ganglia simpatis, berjalan di tunika adventitia arteri renalis dan menginervasi segmen perifer korteks renalis, kemudian berakhir di arteriol glomerulus. ${ }^{17}$ Aktivasi serabut saraf efferen ginjal menyebabkan retensi garam dan cairan dan aktivasi sistem renin-angiotensin-aldosteron, yang pada akhirnya meningkatkan tekanan darah. $^{10}$ Selain itu, aktivasi saraf ini juga menyebabkan penglepasan noreprinefrin dari ujung saraf pada korteks ginal dapat menyebabkan peningkatan $30-40 \%$ penyerapan air dan sodium serta vasokonstriksi arteri renalis. ${ }^{17}$ Pada pasien yang mengalami hipertensi esensial, umumnya ditemukan aktivitas simpatik yang berlebihan pada nervus renalis yang dibuktikan dengan peningkatan kadar noreprinefirn yang dikeluarkan oleh saraf simpatik ginjal dan peningkatan aktivitas simpatik secara umum. ${ }^{9}$

Renal denervation adalah prosedur ablasi nervus renalis dengan menggunakan radiofrekuensi untuk mengurangi aktivitas simpatik saraf renalis sehingga dapat menurunkan tekanan darah. ${ }^{18}$ Percobaan preklinis pada hewan coba dan beberapa studi klinis pada manusia menunjukan hasil yang baik pada penurunan tekanan darah. ${ }^{18}$ Ada beberapa teknik renal denervation, antara lain reseksi saraf splanknik ginjal, kateter Radiofrequency Ablation (RFA), dan yang terbaru, High-Intensity Focused Ultrasound (HIFU). ${ }^{18}$

Teknik pertama yang diperkenalkan dalam renal denervation adalah reseksi. Hasil evaluasi menunjukkan adanya penurunan tekanan darah dan hilangnya gejala pada pasien yang sebelumnya mengalami hipertensi maligna. ${ }^{17}$ Cara ini sudah tidak dipakai karena penemuan obat antihipertensi yang efektif dan risiko dari 
teknik pembedahan yang invasif. ${ }^{8}$ Metode selanjutnya adalah menggunakan metode kateter Radiofrequency Ablation (RFA) yang mendapatkan hasil yang cukup memuaskan pada beberapa studi. ${ }^{9}$ Metode ini dilakukan dengan cara memasukan kateter melalui arteri femoralis menuju arteri renalis kemudian ditembakkan energi radiofrekuensi sehingga menimbulkan ablasi pada nervus renalis. ${ }^{9}$ Namun kekurangan metode ini adalah ketidakmampuan kateter untuk menjangkau arteri berdiameter $<4 \mathrm{~mm}$, risiko kerusakan endotel, rasa sakit yang dialami oleh pasien dan risiko dari prosedur yang invasif. ${ }^{19}$ Perkembangan terbaru teknik RDN adalah dengan menggunakan pendekatan non-invasif menggunakan High-Intensity Focused Ultrasound (HIFU). ${ }^{11}$ Teknik HIFU dianggap lebih meminimalkan efek samping dibanding metode invasif yang dikembangkan sebelumnya dan menghasilkan luaran yang menjanjikan. ${ }^{11}$

\section{High Intensity Focused Ultrasound (HIFU)}

High Intensity Focused Ultrasound (HIFU) adalah metode non-invasif untuk ablasi jaringan yang menghancurkan jaringan dengan tembakan ultrasound berintensitas tinggi pada sebuah fokus kecil. ${ }^{8}$ Pada titik fokus, terjadi peningkatan suhu hingga $60-90^{\circ} \mathrm{C}$ yang menyebabkan kerusakan jaringan dan meninggalkan batas antara jaringan yang rusak dengan jaringan normal disekitarnya selebar kurang dari 10 sel. $^{8}$ Beberapa jenis perangkat HIFU yang dapat digunakan untuk renal denervation telah dikembangkan, antara lain Medical Surround Sound ${ }^{\mathrm{TM}}$ (Kona Medical, Inc., Bellevue, Washington, USA), JC HIFU tumour therapeutic system (Chongqing Haifu Technology Co. Ltd., Chongqing, China), dan ExAbate 2000 (InSightecTxSonics, Haifa, Israel). ${ }^{19}$ Perangkat Medical Surround Sound ${ }^{\mathrm{TM}}$ dan JC HIFU tumour therapeutic system menggunakan perangkat pencitraan berbasis USG Doppler untuk memandu mengarahkan HIFU ke titik target nervus renalis, sedangkan ExAbate 2000 menggunakan perangkat berbasis Magnetic Resonance Imaging (MRI) sebagai alat pemandu. ${ }^{19}$

\section{Efektivitas HIFU pada Hipertensi Resisten}

Beberapa penelitian telah dilakukan untuk mengetahui efektivitas dan efek samping terapi HIFU pada hipertensi, mulai dari penelitian pada hewan coba hingga studi klinis pada manusia. Penelitian pada hewan coba pernah dilakukan pada anjing ${ }^{11}$ dan babi. ${ }^{8,10,16}$ Dari penelitian tersebut didapatkan penurunan tekanan darah yang signifikan, yakni 15,9 mmHg pada tekanan sistolik dan 13,6 mmHg pada tekanan diastolik. ${ }^{11}$ Ditemukan pula penurunan kadar norepinepfrin ${ }^{8}$ dan tidak ditemukan adanya kerusakan jaringan sekitar seperti kulit, hepar, lien, ginjal, ureter dan usus halus. ${ }^{11}$

Studi klinis pada manusia menunjukkan hasil yang cukup baik. Penurunan tekanan darah ditinjau kembali pada minggu ke-3, 6, 12, 24, dan 52 paska intervensi. Pemeriksaan serum kreatinin, blood urea nitrogen (BUN), dan laju filtrasi glomerulus tidak mengalami peningkatan. ${ }^{18}$ Pada pemeriksaan vaskular dan fungsi ginjal, tidak didapatkan adanya kerusakan vaskular ataupun malfungsi ginjal. Fungsi sensorik dan motorik pun tidak terganggu. ${ }^{20}$ Efek samping yang dilaporkan dari metode ini adalah nyeri punggung, yang terjadi pada $41 \%$ pasien yang melakukan prosedur renal denervation menggunakan metode HIFU. ${ }^{20}$ Namun dari keseluruhan pasien yang mengalami nyeri punggung, setelah diberikan obat penghilang nyeri, nyeri punggung sudah tidak dirasakan lagi. ${ }^{20}$

\section{Penutup}

Hipertensi resisten adalah keadaan tekanan darah yang tetap tinggi meskipun telah menggunakan kombinasi minimal tiga macam obat anti hipertensi. Hipertensi resisten meningkatkan risiko penyakit kardiovaskular lebih tinggi daripada hipertensi yang terkontrol. High Intesity Focused Ultrasound (HIFU) merupakan metode non-invasif yang efektif dan aman dalam mengendalikan hipertensi resisten.

\section{Daftar Pustaka}

1. Badan Penelitian dan Pengembangan Kesehatan RI. Hasil utama riset kesehatan dasar 2018. Jakarta: Kementerian Kesehatan RI;2018.

2. World Health Organization (WHO). Fact Sheets: Hypertension [Internet]. 2019. [Diakses pada 24 Desember 2019] Tersedia Arizandi R. Jkdoktmeditek.2020; 26(1): 31-35 
di https://www.who.int/news-room/factsheets/detail/hypertension

3. Badan Pusat Statistik. Penduduk Indonesia menurut Provinsi 1971, 1980, 1990, 1995, 2000 dan 2010 [Internet]. 2019. [Diakses pada 24 Desember 2019] Tersedia di https://www.bps.go.id/statictable/2009/02/ 20/1267/penduduk-indonesia-menurutprovinsi-1971-1980-1990-1995-2000-dan2010.html2017

4. American Heart Association. 2017 Guideline for the prevention, detection, evaluation, and management of high blood pressure in adults. J Am Coll Cardiol. Sep 2017;23976; DOI: 10.1016/j.jacc.2017.07.745

5. Ripley TL, Babato A. PSAP Book 1 Cardiology: Hypertension. New York: AACP;2018

6. Oparil S, Schmieder RE. New Approaches in the treatment of hypertension. Circ Res. 2015;116(6): 1074-95.

7. Alexander V V., Shi Z, Iftekher F, Welsh MJ, Gurm HS, Rising G, et al. Renal denervation using focused infrared fiber lasers: A potential treatment for hypertension. Lasers Surg Med. 2014;46(9): 689-702.

8. Freyhardt P, Heckmann L, Beck A, Stolzenburg N, Schnorr J, Kamp J, et al. MR-Guided high-focused ultrasound for renal sympathetic denervation - a feasibility study in pigs. J Ther Ultrasound. 2014;2(1): 1-10.

9. Esler MD, Böhm M, Sievert H, Rump CL, Schmieder RE, Krum H, et al. Catheterbased renal denervation for treatment of patients with treatment-resistant hypertension: 36 month results From The SYMPLICITY HTN-2 randomized clinical trial. Eur Heart J. 2014;35(26): 1752-9.

10. Chernin G, Szwarcfiter I, Bausback Y, Jonas M. Renal sympathetic denervation system via intraluminal ultrasonic ablation: Therapeutic intravascular ultrasound design and preclinical evaluation. J Vasc Interv Radiol. 2017;28(5): 740-8.

11. Wang Q, Guo R, Rong S, Yang G, Zhu Q, Jiang $\mathrm{Y}$, et al. Noninvasive renal sympathetic denervation by extracorporeal high-intensity focused ultrasound in a preclinical canine model. J Am Coll Cardiol. 2013;61(21): 2185-92.
12. Pujasari A, Setyawan H, Udiyono A. Faktor-faktor internal ketidakpatuhan pengobatan hipertensi di puskesmas Kedungmundu Kota Semarang. J Kes Mas 2015;3(3): 99-108.

13. Judd E, Calhoun DA. Apparent and true and resistant hypertension: Definition, prevalence and outcomes. J Hum Hypertens. 2014;28(8): 463-8.

14. Giannattasio C, Cairo M, Cesana F, Alloni M, Sormani P, Colombo G et al. Blood pressure control in Italian essential hypertensives treated by general practitioners. Am J Hypertens 2012;25: 1182-7.

15. Sim JJ, Bhandari SK, Shi J, Liu IL, Calhoun DA, McGlynn EA et al. Characteristics of resistant hypertension in a large, ethnically diverse hypertension population of an integrated health system. Mayo Clin Proc 2013; 88: 1099-107.

16. Shea J, de Bever J, Kholmovski E, Beal H, Hadley JR, Minalga E, et al. Effect of applied energy in renal sympathetic denervation with magnetic resonance guided focused ultrasound in a porcine model. J Ther Ultrasound. 2017;5(1): 1-10.

17. Papademetriou V, Rashidi AA, Tsioufis C, Doumas M. Renal nerve ablation for resistant hypertension: How did we get here, present status, and future directions. Circulation. 2014;129(13): 1440-51.

18. Rong S, Zhu H, Liu D, Qian J, Zhou K, Zhu $\mathrm{Q}$, et al. Noninvasive renal denervation for resistant hypertension using high-intensity focused ultrasound. Hypertension. 2015;66(4): 22-5.

19. Schmieder RE, Ott C, Bramlage P. Noninvasive renal denervation: Update on external ultrasound approaches. Curr Hypertens Rep [Internet]. 2016;18(6):1-7. Available from: http://dx.doi.org/10.1007/s11906-0160653-6

20. Neuzil P, Ormiston J, Brinton TJ, Starek Z, Esler M, Dawood O, et al. Externally delivered focused ultrasound for renal denervation. JACC Cardiovasc Interv. 2016;9(12): 1292-9.

21. Yaxley JP, Thambar SV. Resistant hypertension: An approach to management in primary care. J Fam Med Prim Care. 2015;4(2): 193-9. 